\title{
International organizations and development finance: Introduction to the special issue
}

\author{
Daniel L. Nielson ${ }^{1} \cdot$ Bradley Parks $^{2}$. \\ Michael J. Tierney ${ }^{2}$
}

Every year, states and international organizations (IOs) provide somewhere between $\$ 120$ and $\$ 170$ billion in official development finance (ODF) to recipient countries. IOs are typically responsible for about one-third of global ODF, with sovereign governments providing the remainder. ${ }^{1}$ The fact that IO development finance comes from many countries acting jointly distinguishes it from bilateral development finance. IOs typically aggregate the preferences and resources of multiple member states in the pursuit of a collective policy among their own ranks and toward other countries.

This means that development finance from international organizations represents a distinct institutional form of aid-giving and lending that stands apart from bilateral financing. The multilateral nature of IO development finance - requiring member governments to negotiate and agree upon shared policies - may alter the underlying politics and motivations driving multilateral aid as compared to bilateral aid. But is assistance from international organizations actually different in its causes and consequences? Does divergence in institutional form lead to differences in content and function? Are the underlying motivations of IOs truly distinct from their bilateral counterparts? Does IO development finance have different effects on recipients? ${ }^{2}$ And how are new governance arrangements

\footnotetext{
${ }^{1}$ These summary statistics are based on the OECD's definitions and measurements of ODF over 1985-2015 period and estimated missing flows that are not captured in OECD statistics. See Tierney et al. (2011), Strange et al. (2017) and OECD statistics at: http://www.oecd.org/dac/stats/statisticsonresourceflowstodevelopingcountries.htm. ${ }^{2}$ For existing empirical studies that compare the effectiveness of bilateral and multilateral development finance, see Ram (2003, 2004), Headey (2008), Minoiu and Reddy (2007, 2010), Alvi and Aberra (2012), and Kizhakethalackal et al. (2013). Gulrajani (2016) provides a useful review of the literature on the distinctive features of multilateral development finance and how it has changed over the past decade.
}

Daniel L. Nielson

dan_nielson@byu.edu

1 Brigham Young University, Provo, UT, USA

2 College of William and Mary, Williamsburg, VA, USA 
at multilateral agencies, such as the inclusion of non-state actors on governing boards and the increasing use of trust funds, likely to shape the allocation and the effects of IO development finance going forward?

Scholars have made progress answering some of these questions, but many empirical and theoretical issues remain unresolved. At least three challenges have constrained research on IO development finance. First, data coverage on development finance has been primarily limited to time-series-cross-section statistics covering organizations by year. These data usually fail to capture the nuances of how money flows from member governments and debt markets to the IOs themselves and then on to recipient governments, private contractors, and non-governmental organizations before reaching the nominal beneficiaries of aid. Do these long and multifaceted chains of delegation differentiate multilateral financing from the bilateral baseline in any meaningful or consequential ways? Can more complete and accurate data coverage of these flows increase our understanding of the politics and the effects of IO development finance?

Second, data on IO development finance have generally been aggregated broadly across sectors, geographies, distribution channels, implementation partners, and financial modalities, among other things. This reliance on highly aggregated data likely results in important inferential errors that greater granularity, local specificity, and tracking of delivery channels would reveal. Do international organizations target aid by sector or geography in ways that are similar to or different from bilateral donors? Are the paths by which money gets channeled to recipients similar? Are the fiduciary, social, and environmental standards followed by bilateral and multilateral suppliers of development finance substantially different? Are multilateral institutions any better than bilateral institutions at providing useful analytical and advisory support to their in-country partners? Have the sectors or geographic targets of IO assistance changed over time? Answering these questions requires more disaggregated data on both multilateral and bilateral financial flows.

Third, the nature of the aid enterprise often limits the methods that can be used to acquire new knowledge. While several development organizations, including the World Bank, have made random assignment of development interventions a priority within specific countries and sectors in order to evaluate programs and obtain precise estimates of causal effects, random assignment of all aid across countries has not been and almost certainly never will be seriously considered. This fact limits most empirical inquiry to observational research, making causal estimation of aid effectiveness more difficult, and complicating efforts to understand whether, when, and how aid from different types of donors lead to different results on the ground. Do multilateral donors allocate aid differently? Does IO aid have different intended or unintended effects on the nominal beneficiaries of aid when compared to bilateral flows? Do these beneficiaries perceive IO aid as more or less valuable compared to bilateral assistance? New applications of experimental methods and econometric techniques that aim to isolate the causal effects of different interventions hold some promise in answering these questions.

The articles in this special issue address all three of these challenges in by improving data coverage, employing more granular data, or using new methods to answer the types of questions articulated above. But before summarizing the contributions in this special issue, we first describe the ways in which development finance from international organizations differs in form from traditional bilateral aid. We then 
elaborate on the three research challenges introduced above and describe how the political economy literature has started to make progress in addressing these challenges.

\section{The distinctiveness of multilateral development finance}

An important share of development finance from international organizations goes to recipient countries in the form of grants that the beneficiaries do not repay. Many IOs, including most of the specialized UN agencies, provide their development assistance in the form of grants. In terms of endowments without repayment, then, these grants look very similar to most bilateral assistance.

However, the process of grant allocation from multilateral organizations can look very different in practice when compared to allocation from bilateral agencies. This stems largely from the collective decision-making that characterizes the multilateral financial institutions (Nielson and Tierney 2003; Hawkins et al. 2006; Copelovitch 2010). In most IOs that provide development assistance, member governments are comprised of both wealthier donor countries and poorer recipient countries whose representatives jointly bargain, coalesce, and vote on policies that guide aid allocation and/or on specific proposals for development projects and programs (Lyne et al. 2006, 2009; Murphy 2006). In institutional form this contrasts with bilateral aid agencies, which make unilateral decisions over their aid portfolios while consulting minimally - despite consistent calls from development advocates for greater coordination - with agencies from other donor countries. So, there are key differences in process between bilateral and multilateral development assistance.

However, when it comes to multilateral development banks (MDBs) such as the World Bank and the various regional development banks, which provide the majority of IO development finance, there are also differences in the types of financial instruments that are employed. MDBs provide no-interest loans with relatively minor fees and very long (often 50-year) payback schedules of which only the principal needs to be repaid. The most well known of these institutions is the International Development Association (IDA) at the World Bank, but each regional development bank has a similar lending window that provides no-interest or very low-interest loans. Since principal amounts are repaid with currency that is usually inflating - even if only modestly - over time, these financial instruments are very attractive to recipients. Often referred to as the "soft windows" at the development banks, these exceedingly concessional loans are effectively grants and are referenced as such at the MDBs.

And finally, in addition to grants, the development banks also issue low-interest loans to borrowers from their "hard windows." For decades the rates on these loans have significantly undercut what many borrower countries could obtain from commercial lenders in global debt markets. Thus, due to their historically low interest rates, for decades the grant elements on these MDB loans exceeded the 25\% threshold that qualify them as official development assistance (ODA). ${ }^{3}$ There are many variations on

\footnotetext{
${ }^{3}$ The relative attractiveness of borrowing from these "hard windows" at the MDBs has declined in recent years due, in part, to historically low global interest rates. What were traditionally the MDB's largest borrowers now have more sovereign borrowing options and can sometimes acquire loans on similar terms from commercial banks (Humphrey 2014).
} 
the themes of these financial instruments, and the contributions to this special issue explore their different aspects. But it is important to emphasize that financial instruments differ significantly across IO development agencies. ${ }^{4}$

The distinctiveness of the MDBs' soft- and hard-window assistance compared to conventional aid (e.g., grants) brings with it different political and financing demands. The soft windows at the MDBs have traditionally been funded primarily by periodic allocations from member governments. However, more recently, MDBs have chosen to leverage their AAA bond ratings on international debt markets to supplement funding for the no-interest soft-window loans to their poorest members (Mayeda 2016). The MDB hard windows are entirely funded by bond floats leveraging member-government capital subscriptions. Chris Humphrey (2017) describes this financing dynamic in his contribution to this special issue. As he explains, changes in sources of funding alter political incentives, and thus the lending patterns of the MDBs.

"Multi-bi" development assistance is another increasingly important type of IO development finance that has surged in recent years (Eichenauer and Reinsberg 2017). For these mostly grant-funded projects, individual governments, or small groups of member governments, provide "earmarked" financing to MDBs in the form of trust funds that are designed to address specific issues. Employing financing from these trust funds, MDB staffs negotiate, design, and implement projects in recipient countries according to the directives of the trust-fund owners rather than the entire membership represented on the Bank boards. These financial mechanisms loosen, or bypass entirely, the traditional governance structures at the MDBs and introduce their own distinctive political dynamics where trust fund owners have more control over allocation than they do core funding from the same MDB.

In addition to grants and loans, multilateral institutions provide substantial and increasing amounts of financing (e.g., loans, guarantees, and equity investment) and risk insurance to private companies in the developing world and to private companies in Western countries willing to invest in developing countries. A growing chorus of policymakers and thought leaders are now calling upon multilateral development institutions to ramp up their support to the private sector in order to facilitate the achievement of the Sustainable Development Goals (e.g., Savoy et al. 2016). ${ }^{5}$ These forms of support to private sector entities are supposed to serve different purposes than the support that multilateral development institutions provide to public sector and nonprofit entities - for example, by encouraging companies to pursue investment activities that they might not otherwise pursue through the provision of risk insurance. However, the factors that guide the cross-national and sub-national allocation of such financial flows are understudied and poorly understood. ${ }^{6}$ Likewise, the economic, social,

\footnotetext{
${ }^{4}$ While none of the contributions to this special issue address the role of MIGA, the IFC or other multilateral organizations designed to incentivize private investments in developing countries, these kinds of institutions are an increasingly important part of the multilateral organizational effort to promote development. For recent work that does address the role of these institutions in the area of development finance see Girishankar (2009), Mason and Asher (2010), Michaelowa and Michaelowa (2011).

${ }^{5}$ Willem te Velde (2011) estimate that these amounts fluctuate between $\$ 15$ billion and $\$ 33$ billion a year during the 2000s.

${ }^{6}$ In principle, these types of financing are supposed to support economic development in countries with limited access to capital markets.
} 
environmental, and political effects of these flows represent a major blind spot in the empirical literature on IO development finance (as we discuss below).

The distinctive political dynamics that are at work within multilateral development finance institutions have been difficult to study given the limitations noted above relating to data coverage, data aggregation, and research methods. Below we discuss each of these elements in greater depth. As we shift to this discussion, we note that the contributions to this special issue do not advance strikingly new theories or paradigms, but instead apply both conventional and novel methods and evidence to address enduring empirical and theoretical questions in the study of foreign aid and development finance.

\section{Data coverage}

An important question in the study of IO development finance is whether and where data coverage is sufficiently complete and accurate to enable rigorous empirical inquiry. Consider the private sector financing and risk mitigation activities of IOs. Publicly available data on the private sector lending and insurance activities of multilateral and bilateral development finance institutions are extremely sparse due to concerns held by private sector clients about the disclosure of commercially-sensitive information that would undermine their competitiveness. As such, it has proven to be particularly challenging for scholars of IO development finance to make significant knowledge gains in this area. ${ }^{7}$

Another key challenge for scholars of IO development finance is the issue of whether the entities with de jure responsibility for monitoring global development finance activities can keep pace with de facto changes in the global development finance regime. Researchers have historically drawn inferences about the allocation and effects of IO development finance based on data that were made available through a voluntary disclosure regime (e.g., the OECD-DAC). This reliance on voluntarily disclosed data was relatively unproblematic when regime compliance was high and when almost all donors were members of the OECD. However, the international development finance regime is currently undergoing a period of unprecedented tumult, with a growing number of non-Western states contesting or opting out of the existing rules and institutions that were designed after World War II (by a group of Western states with relatively homogenous preferences and values) to facilitate coordination and promote a shared approach to development (Hook and Rumsey 2016; Muchapondwa et al. 2016; Dreher et al. forthcoming). ${ }^{8}$

\footnotetext{
7 The largest multilateral institutions that provide such financing are the International Finance Corporation, the European Bank for Reconstruction and Development, and the European Investment Bank. Their largest bilateral counterparts are the German Investment Corporation, the UK's Commonwealth Development Corporation (CDC), France's Promotion and Participation for Economic Cooperation (PROPARCO), and the Netherlands Development Finance Company (FMO). However, there are many other bilateral institutions engaged in the provision of such financing.

${ }^{8}$ Recent challenges to the prevailing international order include China's recent efforts to coordinate emerging powers through the BRICS summits and G-20 meetings and to spearhead the creation of two new international financial institutions of their own: the New Development Bank and the Asian Infrastructure Investment Bank (Biswas 2015).
} 
This period of tumult has two major implications for empirically-oriented researchers. First, for a growing number of multilateral development finance suppliers, there are either no data or insufficiently complete and accurate data. The AIIB and the New Development Bank are obvious cases in point, but even the EBRD had no comprehensive publicly available project level data until 2010 (Tierney et al. 2011). Second, a growing number of bilateral donors and lenders refuse to disclose detailed information about their overseas activities (e.g., China Development Bank, China ExIM Bank, the Brazilian Development Bank, the Development Bank of Southern Africa, the Industrial Development Bank of India, Vnesheconombank, Russian Regional Development Bank, and the Export Development Bank of Iran), so inasmuch as researchers wish to study the distinctiveness of IO development finance by comparing it to bilateral development finance, this type of comparative analysis will become more rather than less difficult in the coming years. The Brazys et al. (2017) contribution to this volume, which compares the local corruption effects of World Bank projects and Chinese projects (using the new open source AidData-TUFF method to identify the latter as explained in Strange et al. 2017), represents one example of how researchers can work around this increasingly binding constraint. However, many more efforts of this type will be needed going forward to ensure that knowledge accumulation about IO development finance (and its distinctiveness) does not slow or degrade over time because of growing informational scarcity.

Other missing data challenges that scholars of IO development finance increasingly face relate to trust funds, pass-along funds, and the flow of money from multilateral organizations to contractors and from contractors to recipients. In this regard, the Eichenauer and Reinsberg (2017), McLean (2017), and Reinsberg (2017) contributions to this special issue represent important attempts to provide more complete and accurate data coverage of IO development finance flows and thus improve our collective understanding of the politics and the effects of such flows. However, IO scholars cannot afford to rest on their laurels; substantially more effort will be needed in the future to ensure that the most important questions about the causes and consequences of IO development finance are empirically tractable. Answering these questions will require more and better data coverage.

\section{Data aggregation}

The contributions to this special issue represent a broader trend in empirical research on the causes and consequences of bilateral and multilateral development finance. For decades the empirical literature aggregated data across dissimilar sources and types of development finance and employed cross-national regression methods in an effort to gauge the nation-wide impact of these financial transfers on aggregated outcomes such as national economic growth or measures of national poverty. In the past decade research has shifted towards new forms of analysis that unbundle development projects into their constituent parts and exploit more granular variation, such as sectoral variation in aid projects (Clemens et al. 2011; Hicks et al. 2008), in-country geographic dispersion of the interventions supported by development projects (Findley et al. 2011), educational training and professional backgrounds of development project managers (Chwieroth 2013), behavioral and ascriptive characteristics of project implementers 
(Denizer et al. 2013), levels and types of due diligence applied during project preparation (Kilby 2015), levels and types of oversight placed on project supervision and performance measurement (Honig 2016), and varying channels of delivery and agents of implementation (Dietrich 2013). These disaggregated measures of aid projects, policy, and personnel enable identification of variation in development outcomes within targeted regions and sectors, which has been a boon to both researchers who aim to understand development finance and practitioners who aim to improve development outcomes.

For example, the Brazys et al. (2017) contribution to this special issue is representative of a broader "geospatial turn" in aid research that leverages subnational sources of variation to better understand the motivations for and impacts of international development finance (Winters 2014; Dreher and Lohmann 2015; Nunnenkamp et al. 2016a, b; Briggs 2017). With data on the precise locations and timing of specific interventions funded by bilateral and multilateral development finance institutions and subnationally geocoded outcome data, the literature is now uncovering new knowledge about the features of multilateral development finance that are truly distinctive. This approach has produced new insights about how multilateral development finance is geographically targeted within countries (Öhler and Nunnenkamp 2014; Briggs 2017; Nunnenkamp et al. 2017) and how these targeting practices differ in consequential ways from the practices of bilateral donors (Dreher et al. 2016). This work also identifies important differences in how multilateral donors coordinate their activities as compared to bilateral donors (Nunnenkamp et al. 2016a, b).

This geo-spatial turn has also led to a new set of aid effectiveness studies that seek to achieve causal identification with finer-grained data on the geographical scope and timing of specific interventions and (both intended and unintended) outcomes that are measured on similar spatial and temporal scales (Dreher and Lohmann 2015; Campbell et al. 2016; Marty et al. 2017). Several of these studies have presented evidence that bilateral and multilateral sources of development finance can have substantially different impacts on economic, environmental, and governance outcomes (Dreher et al. 2016; Buchanan et al. 2016; BenYishay et al. 2016; Isaksson and Kotsadam 2016).

The use of more disaggregated data has also generated new insights about the projectspecific factors that facilitate and impede the successful implementation of development projects. At the World Bank, new evidence suggests that roughly $20 \%$ of the variation in project outcomes can be explained by cross-country differences and $80 \%$ of the variation in project outcomes can be explained by within-country variation (Denizer et al. 2013). Some of the project-level factors that seem to matter include levels of effort devoted to project preparation (Kilby 2015; Bulman et al. forthcoming), the quality of project design (Lodewijk et al. 2013), characteristics of the organizations and the personnel responsible for project management and implementation (Denizer et al. 2013; Farrell 2016; Limodio 2016), and the strength of project monitoring and evaluation systems (Legovini et al. 2015; Moll et al. 2015; Raimondo 2016; Buntaine et al. forthcoming).

Yet, relatively little is known about whether, to what extent, how, and why these project-level factors that enable and constrain the successful implementation of development projects differ between bilateral and multilateral development finance institutions. This is a logical next step for future studies. The growing availability of projectlevel outcome data from both bilateral and multilateral development finance institutions puts this type of analysis within reach (Honig 2016). 


\section{Research methods}

In addition to limitations on the quality and coverage of observational data, research on development assistance suffers from challenges in making causal inferences. This problem is common to many social science fields in which random assignment is impractical or unethical. Donor governments and international organizations face an array of political and moral imperatives that make it unlikely that interventions will ever be assigned at random or even "as-if-at-random" on a large scale. Without randomized experiments or natural experiments, it is difficult to make strong causal claims since statistical correlations established with observational data are subject to unobserved or unobservable confounds. While excellent science can still be accomplished using observational data, social scientists, including those who study development finance, continue to search for credible causal identification strategies.

Some studies have sought to employ natural or quasi-experiments to estimate the causal effects of aid interventions. Some plausible identification strategies or instruments have even been employed in an effort to estimate the effects of international development finance. Carnegie and Marinov (forthcoming) employ one of the most creative and credible approaches by making use of the strict rotation of the presidency of the Council of Europe, in which the presidents in the first six months of the year get to propose the budget - including aid allocations - and do so while favoring their former colonies in aid decisions. The authors leveraged this as-if-at-random exogenous variation to estimate the causal effects of aid on democratization and found a positive and significant effect. The use of similar as-if-at-random variation provides a promising approach to questions about multilateral aid allocation.

While randomized experiments likely will not be implemented across the portfolios of multilateral and bilateral development finance institutions, recent work highlights other ways to employ experimental methods that can make use of random assignment and therefore achieve greater internal validity, albeit in more restricted empirical settings. This is especially the case if one's research objective is to understand the perceptions of individual recipient citizens or elites. Findley et al. (2017) provide one such effort in this special issue, which reflects a growing trend in international development finance research that uses experiments for causal identification (see Buntaine and Prather 2015; Dietrich and Winters 2015; Milner et al. 2016; and Harris et al. forthcoming).

\section{Contributions to the special issue}

Findley et al. (2017) use a survey experiment with behavioral outcomes to understand what features of aid projects shape the perceptions of aid effectiveness in the minds of both Ugandan citizens and members of the Ugandan national parliament. The authors randomly assign the named donor for actual aid projects in the pipeline. This research design illustrates the differences between bilateral and multilateral donors in the eyes of individuals within recipient countries. The authors find that there were few meaningful differences for either citizens or MPs across donors and donor types in their willingness to sign supportive petitions, send SMS messages, or, for MPs, to send letters to the Ugandan president. These results 
speak more clearly than previous observational research to hypotheses in the literature on the differences between bilateral, multilateral, and domestic government financing of development projects, at least in the minds of recipients on the ground.

Brazys et al. (2017) use sub-nationally georeferenced observational data to explore how different sources and types of international development finance affect local governance outcomes. As noted above, their article is part of a larger "geospatial turn" in research on development finance. The authors find that the presence of Chinese development projects in localities within Tanzania is associated with higher levels of self-reported experiences with corruption by local residents. However, when World Bank development projects are located in a given locality, self-reported experiences with corruption are lower. In cases where Chinese and World Bank projects are physically co-located, however, the apparent corruption-reducing effect of World Bank aid vanishes. Whether this finding is robust across other recipient countries and other donors will certainly be the subject of future research, but this initial finding will no doubt generate interest in both the research and policy communities where corruption has been identified as a key constraint on improving developing outcomes.

McLean (2017) employs contract-level data to gain leverage on the puzzle of multilateral aid allocation. Adopting an informal influence approach (see Stone 2013), she studies the distribution of contracts at the World Bank to learn whether companies headquartered in either recipient countries or in the countries of their major bilateral donors have advantages in winning contract bids. She finds that contracts are indeed granted disproportionately to recipients' domestic companies and their largest bilateral aid donors. Her contribution, as we previously noted, is part of a larger effort in the literature to unbundle aid projects into their constituent parts and study the causes and consequences of IO development finance at these finer scales.

Humphrey (2017) employs a variety of qualitative methods to reveal what may be the most striking finding in this special issue - an untold and important story about "new" external actors that shape the operational lending decisions at the largest MDBs. This research on the role of Credit Rating Agencies (CRAs) shows how extant theoretical approaches, such as principal-agent theory, have understated the influence of these under-studied actors. More importantly, Humphrey shows that post-financial crisis changes in the way CRAs calculate the credit risk of MDB portfolios directly impacts operational decisions at all the major MDBs. So, while these "new" actors were always relevant for MDBs, they have been undertheorized in the academic literature and they are increasingly important in the post-2008 world of development finance. Specifically, the ability of staff to focus on the likely development implications of a project has been reduced and a heightened focus on the impact of any given loan on the bond rating of the MDB now shapes both project design and approval at higher levels of management. While members of MDB management and staff are acutely aware of this change, scholars of IPE in general and multilateral development finance in particular have been unaware of this shift. The decisions of CRAs are now likely to have large effects on both developing country governments and our theories of IO governance, which often assume stronger accountability to member states than may be warranted. In fact, as 
member governments seek to make their individual investments in MDB concessional windows go further by permitting the sale of bonds to finance operations, ${ }^{9}$ we are likely to observe an increasing influence on the part of bond markets and CRAs in particular.

The articles by Eichenauer and Reinsberg (2017) and Reinsberg (2017) analyze earmarked aid in general and "pass-on funds," which are a specific manifestation of earmarked aid, respectively. Both papers build upon an impressive new dataset that documents the four-fold increase over the past 20 years of a hybrid type of development finance. Earmarked aid is provided by one or more governments, but is allocated and implemented by staff from an international organization. Previous research (Lyne et al. 2006; Hicks et al. 2008; Bayram and Graham 2016) describes an increase in noncore funding to multilateral development organizations, but until the creation of this new database, many important research questions on the causes and the consequences of delegation to multilateral development organizations were not testable with systematic evidence. Eichenauer and Reinsberg (2017) show that this type of earmarked funding has increased steadily over time and that it now constitutes about $20 \%$ of all official development finance. Hence, the clear conceptual distinction between bilateral and multilateral aid described above has become empirically less clear over time. Why have states and multilateral organizations shifted funding to this new financial modality and what effects has this modality had on development organizations and development outcomes?

Eichenauer and Reinsberg (2017) show that, despite the claims of the governments that provide these trust funds, the cross-national allocation of these funds looks much more like bilateral aid than multilateral aid allocated by the same organizations. Further, states may use earmarked funds for a variety of self-interested purposes for which multilateral aid financed through core funding is not as useful. Reinsberg (2017) shifts the focus from government donors of the funds to the strategic goals and behavior of staff and management within multilateral organizations. When IO staff members need to identify resources to fund the initiatives for which they are responsible, they often strike deals with member governments and other units within multilateral organizations in order to sustain their operations. These political and bureaucratic motivations may result in less than optimal allocation of aid from a development perspective. Like the other contributions to this special issue, Eichenauer and Reinsberg use new and improved evidence to highlight the political economy logic of important outcomes within multilateral development finance organizations, within donor governments, and within developing countries.

\section{References}

Alvi, E., \& Aberra, S. (2012). Does foreign aid reduce poverty? Journal of International Development, 24, 955-976.

Bayram, B. \& Graham E. (2016). Financing the United Nations: Explaining variation in how donors provide funding to the UN. Review of International Organizations X: 1-39.

\footnotetext{
${ }^{9}$ See Donan (2016) for a discussion of the recent decision by the World Bank board to allow IDA to raise funds on international debt markets.
} 
BenYishay, A., Parks, B., Runfola, D., \& Trichler, R. (2016). Forest cover impacts of Chinese development projects in ecologically sensitive areas. In AidData Working Paper \#32. Williamsburg: AidData.

Biswas, R. (2015). Reshaping the financial architecture for development finance: the new development banks. LSE Global South Unit Working Paper No. 2/2015. London: London School of Economics and Political Science.

Brazys, S., Elkink, J., \& Kelly, G. (2017). China, the World Bank, and local corruption in Tanzania. Review of International Organizations, 12, 2.

Briggs, R. (2017). Does foreign aid target the poorest? International Organization, 71(1), 187-206.

Buchanan, G. M., Parks, B. C., Donald, P. F., O'Donnell, B. F., Runfola, D., Swaddle, J. P., Tracewski, L., \& Butchart, S. H. M. (2016). The impacts of World Bank development on sites of high biodiversity importance. In AidData Working Paper \#20. Williamsburg: AidData.

Bulman, D., Kolkma, W., \& Kraay, A. (Forthcoming). Good countries or good projects? Comparing macro and micro correlates of World Bank and Asian Development Bank project performance. Review of International Organizations.

Buntaine, M. T., \& Prather, L. (2015). Providing imperfect public goods: cost effectiveness and preferences for private and public international climate transfers. Unpublished manuscript.

Buntaine, M., Parks, B., \& Buch, B. (Forthcoming). Aiming at the wrong targets: the difficulty of improving domestic institutions with international aid. International Studies Quarterly.

Campbell, S., Findley, M., \& Walker, D. (2016). The micro-dynamics of peacebuilding: a quasi-experimental spatial impact evaluation in Burundi. APSA 2016 Conference Paper.

Carnegie, A., \& Marinov, N. (Forthcoming). Foreign aid, human rights and democracy promotion: evidence from a natural experiment. American Journal of Political Science.

Chwieroth, J. (2013). "The silent revolution:” How the staff exercise informal governance over IMF lending. Review of International Organizations, 8, 265-290.

Clemens, M. A., Radelet, S., Bhavnani, R. R., \& Bazzi, S. (2011). Counting chickens when they hatch: timing and the effects of aid on growth. The Economic Journal, 122, 590-617.

Copelovitch, M. (2010). The international monetary fund in the global economy: banks, bonds, and bailouts. UK: Cambridge University Press.

Denizer, C., Kaufmann, D., \& Kraay, A. (2013). Good countries or good projects? Macro and micro correlates of World Bank project outcomes. Journal of Development Economics, 105, 288-302.

Dietrich, S. (2013). Bypass or engage? Explaining donor delivery tactics in foreign aid allocation. International Studies Quarterly, 57, 698-712.

Dietrich, S., \& Winters, M. S. (2015). Foreign aid and government legitimacy. Journal of Experimental Political Science, 2(2), 164-171.

Donan, S. (2016). World Bank looks to tap markets for lending to poorest countries. Financial Times, September 22, Accessed at https://www.ft.com/content/31b0169c-80da-11e6-8e50-8ec15fb462f4.

Dreher, A., \& Lohmann, S. (2015). Aid and growth at the regional level. Oxford Review of Economic Policy, $31(3-4), 420-446$.

Dreher, A., Fuchs, A., Hodler, R., Parks, B. C., Raschky, P. A., \& Tierney, M. J. (2016). Aid on demand: African leaders and the geography of China's foreign assistance. AidData Working Paper \#3 Revised. Williamsburg: AidData.

Dreher, A., Fuchs, A., Parks, B., Strange, A. M., Tierney, M. J. (Forthcoming). Apples and dragon fruits: the determinants of aid and other forms of state financing from China to Africa. International Studies Quarterly.

Eichenauer, V., \& Reinsberg, B. (2017). What determines earmarked funding to international development organizations? Evidence from the new multi-bi aid dataset. Review of International Organizations, 12, 2.

Farrell, J. (2016). How do Chinese contractors perform in Africa? Evidence from World Bank projects. In SAIS China Africa research initiative working paper \#3. Washington DC: SAIS China Africa Research Initiative.

Findley, M., Powell, J., Strandow, D., \& Tanner, J. (2011). The localized geography of foreign aid: a new dataset and application to violent armed conflict. World Development, 39(11), 1995-2009.

Findley, M. G., Milner, H. V., \& Nielson, D. L. (2017). The choice among aid donors: the effects of multilateral vs. bilateral aid on recipient behavioral support. Review of International Organizations, 12, 2.

Girishankar, N. (2009). Innovating development finance-from financing sources to financial solutions. World Bank Policy Research Working Paper No. 5111.

Gulrajani, N. (2016). Bilateral versus multilateral aid channels: strategic choices for donors. London: Overseas Development Institute.

Harris, A., Milner, H., Findley, M., \& Nielson, D. (Forthcoming). Who controls foreign aid? Elite versus public perceptions of donor influence in aid-dependent Uganda. International Organization. 
Hawkins, D., Lake, D., Nielson, D., \& Tierney, M. (Eds.). (2006). Delegation and agency in international organizations. New York: Cambridge University Press.

Headey, D. (2008). Geopolitics and the effect of foreign aid on economic growth: 1970-2001. Journal of International Development, 20(2), 161-180.

Hicks, Robert, Bradley Parks, Timmons Roberts, and Michael Tierney. 2008. Greening aid: understanding the environmental impact of development assistance. Oxford Univ. Press.

Honig, D. (2016). When reporting undermines performance: the costs of politically constrained organizational autonomy in foreign aid implementation. Working Paper.

Hook, S., \& Rumsey, J. (2016). The development aid regime at fifty: policy challenges inside and out. International Studies Perspectives., 17, 55-74.

Humphrey, C. (2014). The politics of loan pricing in multilateral development banks. Review of International Political Economy, 21(3), 611-639.

Humphrey, C. (2017). The principal in the shadows: credit rating agencies and multilateral development banks. Review of International Organizations, 12, 2.

Isaksson, A.-S., \& Kotsadam, A. (2016). Chinese aid and local corruption. AidData Working Paper \#33. Williamsburg: AidData.

Kilby, C. (2015). Assessing the impact of World Bank preparation on project outcomes. Journal of Development Economics, 115, 111-123.

Kizhakethalackal, E. T., Mukherjee, D., \& Alvi, E. (2013). Quantile regression analysis of health-aid and infant mortality: a note. Applied Economics Letters, 20(13), 1197-1201.

Legovini, A., Di Maro, V., \& Piza, C. (2015). Impact evaluation helps deliver development projects. World Bank Policy Research Working Paper 7157.

Limodio, N. (2016). Manager assignment and project returns: evidence from the World Bank. In STICERD EOPP Discussion Paper \# 61. London: London School of Economics and Political Science.

Lodewijk, S., Knack, S., \& Molenaers, N. (2013). Political ideology, quality at entry and the success of economic reform programs. Review of International Organizations, 8, 447-476.

Lyne, M., Nielson, D., \& Tierney, M. (2006). Getting the model right: single, multiple, and collective principals in development aid. In D. Hawkins, D. Lake, D. Nielson, \& M. Tierney (Eds.), Delegation and agency in international organizations. New York: Cambridge University Press.

Lyne, M., Nielson, D., \& Tierney, M. (2009). Controlling coalitions: social lending at the multilateral development banks. Review of International Organizations, 4(4), 407-433.

Marty, R., Dolan, C. B., Leu, M., \& Runfola, D. (2017). Taking the health aid debate to the subnational level: the impact and allocation of foreign health aid in Malawi. BMJ Global Health, 2(1), e000129.

Mason, E. S., \& Asher, R. E. (2010). The World Bank since Bretton Woods: the origins, policies, operations, and impact of the international bank for reconstruction and development and the other members of the World Bank group: The international finance corporation, the international development association [and] the international centre for settlement of investment disputes. Brookings Institution Press.

Mayeda, A. (2016). World bank commits $\$ 75$ billion for globe's poorest countries. In Bloomberg News .Accessed at https://www.bloomberg.com/news/articles/2016-12-15/world-bank-commits75-billion-for-globe-s-poorest-countries

McLean, E. (2017). The politics of contract allocation in multilateral aid organizations. Review of International Organizations, 12, 2.

Michaelowa, A., \& Michaelowa, K. (2011). Climate business for poverty reduction? The role of the World Bank. Review of International Organizations., 6, 259.

Milner, H., Nielson, D. L., \& Findley, M. G. (2016). Citizen preferences and public goods: comparing preferences for foreign aid and government programs in uganda. Review of International Organizations, 11(2), 219-245.

Minoiu, C., \& Reddy, S. G. (2007). Aid does matter, after all: revisiting the relationship between aid and growth. Challenge, 50(2), 39-58.

Minoiu, C., \& Reddy, S. G. (2010). Development aid and economic growth: a positive long-run relation. The Quarterly Review of Economics and Finance, 50(1), 27-39.

Moll, P., Saavedra, P., \& Geli, P. (2015). Correlates of success in World Bank development policy lending. World Bank: World Bank Policy Research Working Paper Series. Washington DC.

Muchapondwa, E., Nielson, D., Parks, B. C., Strange, A. M., \& Tierney, M. J. (2016). Ground-truthing chinese development finance in africa: field evidence from South Africa and uganda. Journal of Development Studies, 52(6), 780-796.

Murphy, C. (2006). The united nations development programme: a better way? Cambridge: Cambridge University Press. 
Nielson, D., \& Tierney, M. (2003). Delegation to international organizations: agency theory and World Bank environmental reform. International Organization, 57(2), 241-276.

Nunnenkamp, P., Rank, M., \& Thiele, R. (2016a). Aid fragmentation and donor coordination in Uganda: A district-level analysis. In S. Klingebiehl, T. Mahn, \& M. Negre (Eds.), The fragmentation of aid: concepts, measurement, and implications for development policy. Palgrave-McMillan: Rethinking International Development Series.

Nunnenkamp, P., Sotirova, A., \& Thiele, R. (2016b). Do aid donors specialize and coordinate within recipient countries? The case of Malawi. Development Policy Review, 34(6), 831-849.

Nunnenkamp, P., Öhler, H., \& Sosa Andrés, M. (2017). Need, merit, and politics in multilateral aid allocation: a district-level analysis of World Bank projects in India. Review of Development Economics, 21(1), 126-156.

Öhler, H., \& Nunnenkamp, P. (2014). Needs-based targeting or favoritism? The regional allocation of multilateral aid within recipient countries. Kyklos, 67(3), 420-446.

Raimondo, E. (2016). What difference does good monitoring and evaluation make to World Bank project performance? World Bank Policy Research Working Paper No. 7726.

Ram, R. (2003). Roles of bilateral and multilateral aid in economic growth of developing countries. Kyklos, 56(1), 95-110.

Ram, R. (2004). Recipient country's 'policies' and the effect of foreign aid on economic growth in developing countries: additional evidence. Journal of International Development, 16(2), 201-211.

Reinsberg, B. (2017). Organizational reform and the rise of trust funds: lessons from the World Bank. Review of International Organizations, 12, 2.

Savoy, C. M., Carter, P., \& Lemma, A. (2016). Development finance institutions come of age: policy engagement, impact, and new directions. Washington DC: Center for Strategic and International Studies and the Overseas Development Institute.

Stone, R. W. (2013). Informal governance in international organizations: introduction to the special issue. Review of International Organizations, 8(2), 121-136.

Strange, A., Dreher, A., Fuchs, A., Parks, B., \& Tierney, M. J. (2017). Tracking underreported financial flows china's development finance and the aid-conflict nexus revisited. Journal of Conflict Resolution, 61, 4.

Tierney, M., Nielson, D., Darren, H., Roberts, T., Findley, M., Powers, R., Parks, B., Wilson, S., \& Hicks, R. (2011). More dollars than sense: refining our knowledge of development finance using AidData. World Development, 39, 11.

Willem te velde, D. (2011). The role of development finance institutions in tackling global challenges. London: Overseas Development Institute.

Winters, M. (2014). Targeting, accountability and capture in development projects. International Studies Quarterly, 58(2), 393-404. 